\title{
Biosynthesis of Xanthan Gum from Fermenting Shrimp Shell: Yield and Apparent Viscosity
}

\author{
Larissa Alves de Sousa Costa, ${ }^{1}$ Márcio Inomata Campos, ${ }^{1}$ Janice Izabel Druzian, ${ }^{2}$ \\ Ana Maria de Oliveira, ${ }^{3}$ and Enio Nazaré de Oliveira Junior ${ }^{3}$ \\ ${ }^{1}$ Department of Chemical Engineering, Federal University of Bahia, 40210-630 Salvador, BA, Brazil \\ ${ }^{2}$ Department of Chemical Analysis, Federal University of Bahia, 40171-970 Salvador, BA, Brazil \\ ${ }^{3}$ Department of Chemistry, Biotechnology and Bioprocess Engineering, Federal University of São João del Rei, \\ 36420-000 Ouro Branco, MG, Brazil
}

Correspondence should be addressed to Enio Nazaré de Oliveira Junior; enionazare@yahoo.com.br

Received 17 June 2014; Accepted 18 July 2014; Published 10 August 2014

Academic Editor: Long Yu

Copyright (C) 2014 Larissa Alves de Sousa Costa et al. This is an open access article distributed under the Creative Commons Attribution License, which permits unrestricted use, distribution, and reproduction in any medium, provided the original work is properly cited.

With the aim of producing xanthan gum, the effects of an aqueous shrimp shell extract (SSAE) as the source of carbon and nitrogen on the yield and apparent viscosity of the gums produced by fermentation using three native strains of Xanthomonas campestris were studied. It was found that the SSAE contained $89.75 \%$ moisture, $0.054 \%$ ash, $8.069 \%$ protein, 0.787 lipids, and $1.337 \%$ carbohydrates. Media containing different concentrations of SSAE and supplemented with urea $(0.01 \%)$ and phosphate $(0.1 \%)$ were fermented in a shaker, and the results obtained were compared with those obtained from sucrose (control) with the same supplementation and fermentation conditions. Strain 1182 showed the highest yield $\left(4.64 \mathrm{~g} \cdot \mathrm{L}^{-1}\right)$ and viscosity $(48.53 \mathrm{mPa} \cdot \mathrm{s})$, from the medium containing $10 \%(\mathrm{w} / \mathrm{v})$ of SSAE. These values were higher than those obtained from the control medium containing sucrose. Shrimp shell is a low cost residue that can be bioconverted into products of high added value such as xanthan gum.

\section{Introduction}

Xanthan gum is a microbial exopolysaccharide produced by the gram-negative bacterium Xanthomonas campestris by fermenting glucose, sucrose, or other carbohydrate sources. This biopolymer is applied in the food, cosmetic, pharmaceutical, and petrochemical industries and in other sectors as a thickening agent, stabilizer, or emulsifier, and combined with other gums it can act as a gelling agent. Its primary structure is composed of repeating units of pentasaccharides consisting of two glucose, two mannose, and one glucuronic acid residues (Figure 1) [1-5].

Commercially, the hydrocolloid is produced by fermentation using bacterial Xanthomonas campestris and the global xanthan market has progressively increased, at an annual rate of $5-10 \%[6]$.

The carbohydrate source used in the commercial production of xanthan gum is the glucose obtained from corn starch, although sucrose has also been extensively used [1, 2, $7,8]$. The selection of new strains and alternative fermentable substrates, which allow for the production of high yields of high viscosity xanthan gums, has been reported [9-12]. These xanthans may allow one to achieve the desirable sample texture, viscosity, and/or stability at lower concentrations and thus with less color interference and lower end product costs. Mayer et al. [13] studied the specifications of xanthan gum in the exploration of oil and concluded that low concentrations $(0.48 \% \mathrm{~m} / \mathrm{v})$ showed good results. High viscosity xanthan gum has been reported for use in applications such as flavor retention and as immobilization agents.

Statistics from the Brazilian Association of Shrimp Farmers have shown that between 1998 and 2005 the Brazilian shrimp (Litopenaeus vannamei) production increased from 7 thousand to 65 thousand tons/year. This elevated production of shrimp has generated large amounts of solid waste, since the head and shell correspond to $40 \%$ of the total weight and 


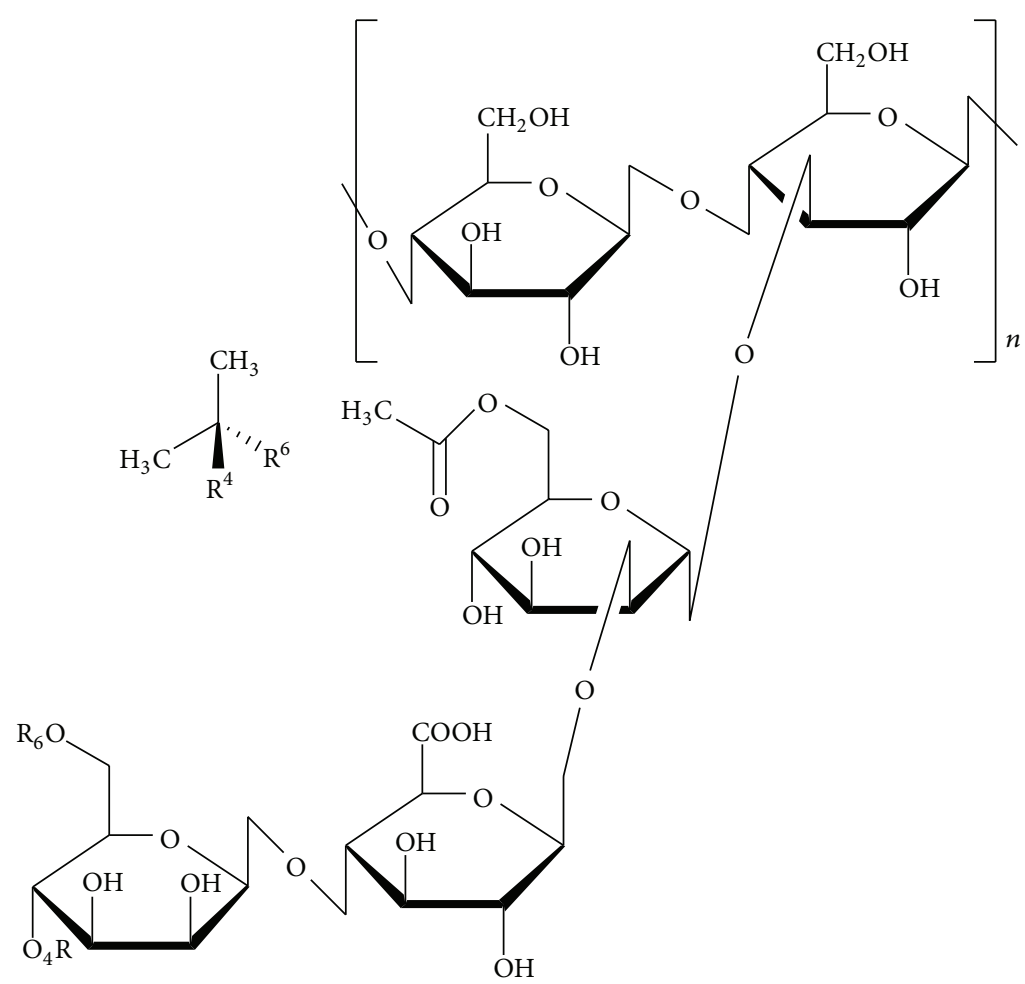

Figure 1: Primary structure of xanthan gum [14].

TABLE 1: Strains of Xanthomonas campestris used in the production of xanthan gum.

\begin{tabular}{ll}
\hline Strain number & \multicolumn{1}{c}{ Specie } \\
\hline 1182 & Xanthomonas campestris pv. manihotis \\
254 & Xanthomonas campestris pv. campestris \\
629 & Xanthomonas campestris pv. campestris \\
\hline
\end{tabular}

cannot be used in the production of animal feed due to their high fiber count, resulting in considerable environmental problems when they are discarded without treatment [15]. The use of alternative substrates such as shrimp shell to produce xanthan gum eliminates the environmental problems of waste disposal producing a biopolymer with high added value at low cost.

This study is innovative in providing specific information to support the design of an aerobic batch bioreactor to produce xanthan gum by fermenting shrimp shell. This paper compares the yields and viscosities of the xanthan gums produced from shrimp shell by three native strains of Xanthomonas campestris with those obtained from the fermentation of sucrose.

\section{Materials and Methods}

2.1. Microorganisms and Cultivation. Three strains of Xanthomonas campestris were obtained from the Collection of Phytobacteria Culture of the Biological Institute (Campinas, Brazil) (Table 1). The strains were cultured on yeast malt
(YM) medium containing ( $\mathrm{w} / \mathrm{v}) 0.3 \%$ yeast extract, $0.3 \%$ malt extract, $0.5 \%$ bacteriological peptone, $1.0 \%$ glucose, and $2.0 \%$ agar.

2.2. Shrimp Shell Composition. The shrimp shells were provided by the Valença da Bahia Maricultura (Salvador, Brazil). They were dried at $60^{\circ} \mathrm{C}$, ground at 50 r.p.m for 10 minutes, and then stored for analysis. The moisture, crude protein, and ash contents were determined according to AOAC [16] and the total lipid contents were determined as described by BLIGH and DYER [17]. The carbohydrates contents were calculated by difference, subtracting the moisture, protein, total lipid, and ash contents from 100\%.

2.3. Shrimp Shell Extract. Shrimp shell suspensions were prepared by dispersing shrimp shell powder in water at $25^{\circ} \mathrm{C}$ and stirring at 400 r.p.m. for 30 minutes. The suspensions were filtered through Whatman paper no. 1 and the filtrates (SSAE) analyzed and used for fermentation.

2.4. Cell Production. To obtain the inoculants, strains of Xanthomonas campestris were cultured in yeast malt (YM) medium $(0.3 \%$ malt extract, $0.3 \%$ yeast extract, $0.5 \%$ bacteriological peptone, and $1.0 \%$ glucose) and incubated at $28^{\circ} \mathrm{C}$ for 24 hours with agitation at 180 r.p.m (orbits per minute) as described by Souza and Vendruscolo [18].

2.5. Xanthan Gum Production. Table 2 shows the formulations of the culture media used for the production of xanthan 
TABLE 2: Compositions of the culture media used for growth of the Xanthomonas campestris strains and for fermentation to produce xanthan gum.

\begin{tabular}{lccc}
\hline Component & $\begin{array}{c}\text { YM } \\
\text { medium }\end{array}$ & $\begin{array}{c}\text { Control } \\
\text { fermentation } \\
\text { medium }\end{array}$ & $\begin{array}{c}\text { Alternative } \\
\text { fermentation } \\
\text { medium }\end{array}$ \\
\hline Glucose $\left(\mathrm{g} \cdot \mathrm{L}^{-1}\right)$ & 10 & - & - \\
Peptone $\left(\mathrm{g} \cdot \mathrm{L}^{-1}\right)$ & 5 & - & - \\
Yeast extract $\left(\mathrm{g} \cdot \mathrm{L}^{-1}\right)$ & 3 & - & - \\
Malt extract $\left(\mathrm{g} \cdot \mathrm{L}^{-1}\right)$ & 3 & - & - \\
Urea $(\%)$ & - & 0.01 & 0.01 \\
$\mathrm{~K}_{2} \mathrm{HPO}_{4}(\%)$ & - & 0.1 & 0.1 \\
Shrimp shell $(\%)$ & - & - & $2-10$ \\
Sucrose $(\%)$ & - & 2 & - \\
\hline
\end{tabular}

gum. The inoculants $(10 \mathrm{~mL})$ were inoculated into $80 \mathrm{~mL}$ of the control fermentation medium contained in $250 \mathrm{~mL}$ conical flasks and of the alternative fermentation medium all previously autoclaved (Table 2) and incubated at $28^{\circ} \mathrm{C}$ for 120 hours with agitation at 250 r.p.m [2, 4, 19]. SSAE concentrations of 2 to $10 \%(\mathrm{w} / \mathrm{v})$ were used to prepare the alternative media, and the $\mathrm{pH}$ adjusted to 7.0.

2.6. Recovery of Xanthan Gum. The fermented broths were centrifuged at $9.626 \times \mathrm{g}$ for 15 minutes to remove the Xanthomonas campestris cells from the supernatants. The xanthan gums were precipitated from the supernatants by adding $96^{\circ} \mathrm{GL}$ ethanol $(3: 1)$. The gum samples were separated and transferred to plates, dried at $40 \pm 2^{\circ} \mathrm{C}$ for $30 \mathrm{~h}$, ground at 50 r.p.m for 10 minutes, and stored for analysis. The yield from each strain was calculated and the values were expressed in $\mathrm{g} \cdot \mathrm{L}^{-1}$ (grams of gum per liter of culture medium) [18].

2.7. Rheology of Xanthan Gums. The rheological behavior of the xanthan gums produced by the Xanthomonas campestris strains was evaluated by apparent viscosity ( $\mathrm{mPa} \cdot \mathrm{s})$, using a Haake Rheotest viscometer with a concentric cylinder device, coupled to a water bath. The apparent viscosities of the samples were determined at $25,45,65$, and $85^{\circ} \mathrm{C}$ and shear rates from 25 to $1000 \mathrm{~s}^{-1}$. The xanthan gum solutions were prepared by dispersing $0.5 \%(\mathrm{w} / \mathrm{v})$ xanthan gum in distilled water. The solutions were homogenized for 40 minutes using a magnetic stirrer at room temperature to complete dissolution and then kept in a refrigerator for 12 hours before making the viscosity measurements.

The effect of shear rate on the viscosities of the xanthan gum solutions was described by the Ostwald-de-Waele kinetic model [20]. Consider

$$
\mu=K(\gamma)^{n-1}
$$

where $K$ is the consistency index, $n$ the flow behavior index, and $\mu$ the absolute viscosity.

The pseudoplastic behavior of the xanthan gum solutions was confirmed by fitting the Ostwald-de-Waele $\left(\mu=K(\gamma)^{n-1}\right)$ model to the experimental data evaluated by regression of the
TABLE 3: Physicochemical characterization of the shrimp shell and the SSAE used as a substrate for fermentation in the production of xanthan gum by three strains of Xanthomonas campestris.

\begin{tabular}{lcc}
\hline Analysis & $\begin{array}{c}\text { Composition } \\
\text { of the shrimp } \\
\text { shell meal (\%) }\end{array}$ & $\begin{array}{c}\text { Composition of the } \\
\text { aqueous extract of } \\
\text { the shrimp shell (\%) }\end{array}$ \\
\hline Moisture & $5.77 \pm 0.02$ & $89.75 \pm 0.02$ \\
Ash & $18.8 \pm 0.09$ & $0.054 \pm 0.01$ \\
Crude protein & $49.74 \pm 0.07$ & $8.069 \pm 0.01$ \\
Total lipids & $4.01 \pm 0.04$ & $0.787 \pm 0.07$ \\
Carbohydrates & $21.68 \pm 0.02$ & $1.337 \pm 0.01$ \\
\hline
\end{tabular}

power law. The values of the consistency index $(K)$, flow index $(n)$, and correlation coefficients $\left(R^{2}\right)$ were calculated by Excel software 2003.

\section{Results and Discussion}

Initially, the physicochemical characterizations of the shrimp shell and the SSAE used as the source of carbon, nitrogen, and other nutrients for cell reproduction by three different strains of Xanthomonas campestris were evaluated (Table 3 ).

It was shown that the shrimp shell contained $5.77 \%$ moisture, $18.8 \%$ ash, $49.74 \%$ protein, and $21.68 \%$ carbohydrates, whereas the SSAE contained $89.75 \%$ moisture, $0.054 \%$ ash, $8.069 \%$ protein, and $1.337 \%$ carbohydrates (Table 3 ). The nutrient contents of the SSAE, basically sources of carbon $(1.337 \%)$ and nitrogen $(49.74 \%)$, were sufficient for cell growth and biosynthesis of the xanthan gum.

According to Assis et al. [21], shrimp waste is basically composed of protein, minerals, chitin, and carotenoids, the contents varying according to species, body part, fishing location and seasonal variation, and so forth. Shrimp wastes from different species produced by industries have shown protein contents between 34.60 and $49.75 \%$, total lipids from 3.78 to $10.50 \%$, and ash contents between 15.75 and $41.35 \%$. Thus the nutrients found in shrimp wastes (Table 3 ), a byproduct from fishing industries, can be used as an alternative low coast substrate to produce xanthan gum.

Figure 2 illustrates the xanthan gums produced from the fermentations of sucrose and SSAE by native strain 629 (Xanthomonas campestris pv. campestris). The different colors and appearances of the xanthan gums can be observed.

The gum obtained from sucrose (Figure 2(b)) was lighter than that obtained from SSAE (Figure 2(a)) due to the pigment astaxanthin present in the shrimp exoskeleton and retained in the biopolymer.

Antunes et al. [10] reported that the productivity of xanthan gum was influenced by the microbial strain, time, and fermentation medium. In order to optimize the fermentation time, yeast malt (YM) medium, a fermentation medium widely used in the literature, was used at different times, and the results for the productions of xanthan gum are shown in Figure 3. It was observed that the highest yields were achieved between 96 and 120 hours, subsequently decreasing. The increase in production of xanthan gum up to 120 hours and 
TABLE 4: Production of xanthan gum from sucrose and from the aqueous extract of the shrimp shell by Xanthomonas campestris strains and the viscosity of the aqueous xanthan gum solutions.

\begin{tabular}{lcccc}
\hline \multirow{2}{*}{ Strains X. campestris } & \multicolumn{2}{c}{ Sucrose } & \multicolumn{2}{c}{ Aqueous extract of the shrimp shell } \\
& Production $^{1}\left(\mathrm{~g} \cdot \mathrm{L}^{-1}\right)$ & Viscosity $^{2}(\mathrm{mPa} \cdot \mathrm{s})$ & Production $^{1}\left(\mathrm{~g} \cdot \mathrm{L}^{-1}\right)$ & $\mathrm{Viscosity}(\mathrm{mPa} \cdot \mathrm{s})$ \\
\hline 1182 & $2.26 \pm 0.1$ & 90.36 & $2.64 \pm 0.1$ & 99.96 \\
254 & $2.20 \pm 0.1$ & 80.74 & $2.60 \pm 0.1$ & 85.59 \\
629 & $1.65 \pm 0.1$ & 86.28 & $1.95 \pm 0.2$ & 86.90 \\
\hline
\end{tabular}

Production of xanthan gum.

${ }^{2} 0.5 \%$ aqueous xanthan gum solution, $25 \mathrm{~s}^{-1}$ and $25^{\circ} \mathrm{C}$.

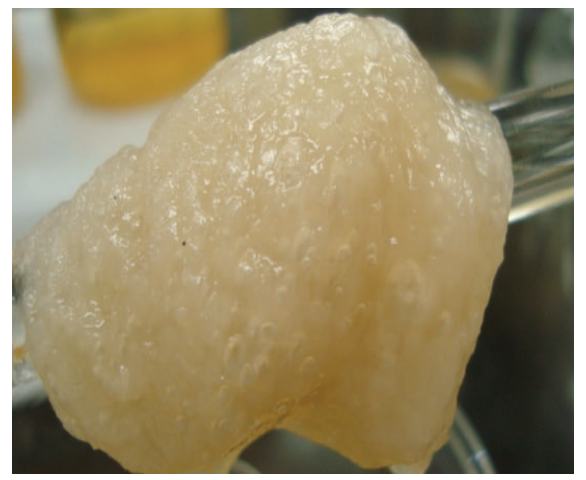

(a)

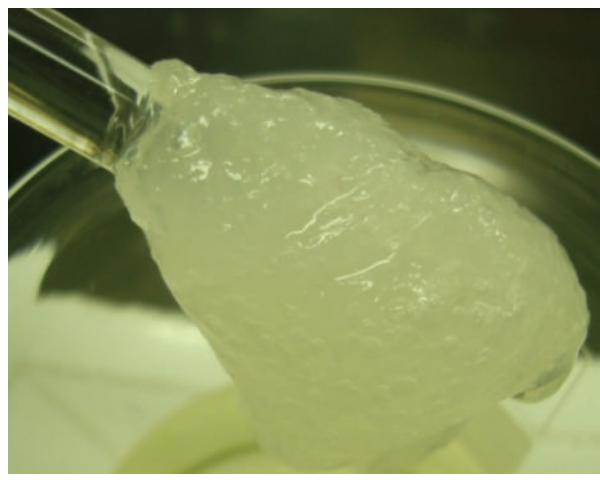

(b)

FIGURE 2: Appearance of the biopolymer produced from the aqueous extract of the shrimp shell (a) and from sucrose (b) precipitated with ethanol.

subsequent decrease were probably caused by polymerizing and hydrolytic enzymes, respectively. Further studies on this topic will be investigated in the authors' laboratory.

Brandão et al. [4] reported a yield of $34.54 \mathrm{gL}^{-1}$ after 120 hours of fermentation with the same strain used in the present study (1182) under the same fermentation conditions $\left(28^{\circ} \mathrm{C}\right.$ and 250 r.p.m) but using sugar cane juice as the alternative substrate.

As shown in Figure 3, the same behavior observed for yield was observed for viscosity, progressively increasing up to 120 hours and then decreasing. The yield increased by $49.4 \%$ between 24 and 120 hours and the viscosity by $64.6 \%$ during the same period.

Table 4 shows the yields and viscosities (shear rate: $25 \mathrm{~s}^{-1}$; temperature: $25^{\circ} \mathrm{C}$ ) of xanthan gums produced by the three different $X$. campestris strains using the control fermentation medium (sucrose) and the alternative fermentation medium (SSAE), both supplemented with urea and $\mathrm{K}_{2} \mathrm{HPO}_{4}$ as shown in Table 2.

In order to establish the best formulation of the medium used to produce xanthan gum, the best $X$. campestris strain and the best fermentation conditions, the alternative medium containing SSAE $(2 \% \mathrm{w} / \mathrm{v})$ was investigated and the xanthan gum was produced compared with that produced by the medium containing sucrose $(2 \% \mathrm{w} / \mathrm{v})$. It was observed that the yields and viscosities values of the xanthan gum produced from SSAE were higher than those produced from sucrose for the three strains studied. The highest viscosity and yield values were obtained using Xanthomonas campestris 1182 as

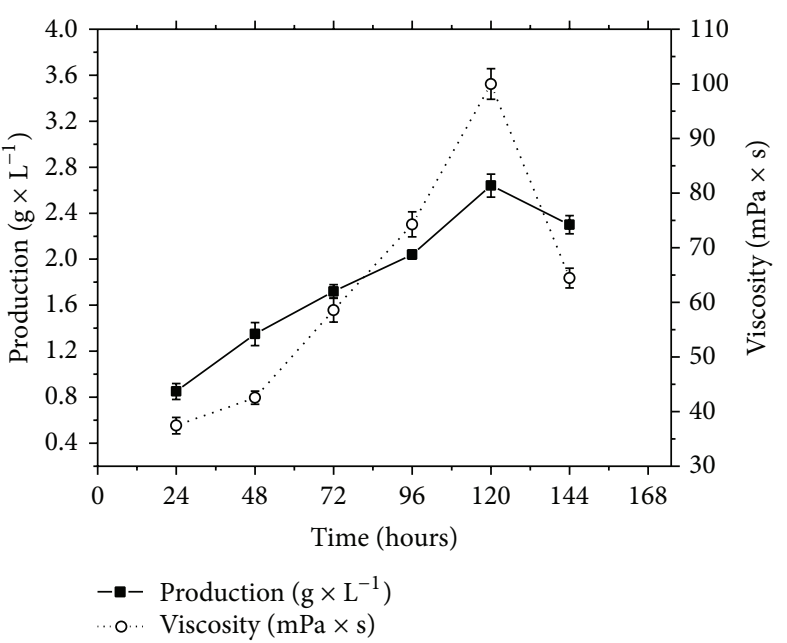

FIgURE 3: Production and viscosity of xanthan gum obtained at different fermentation times by using strain 1182 .

compared to strains 254 and 629, regardless of the substrate used. These results indicate that xanthan gum can be obtained from the alternative medium (SSAE) tested using different strains of Xanthomonas campestris, reducing the production costs since the substrate (SSAE) used as the source of nutrients is waste from the fishing industry.

It is difficult to compare the present results for the yield of xanthan gum with those found by other authors, since the results vary according to the strain used, the 
TABLE 5: Productivity in xanthan gum $\left(\mathrm{g} \cdot \mathrm{L}^{-1}\right)$ and viscosity $(\mathrm{mPa} \cdot \mathrm{s})$ by strains of Xanthomonas campestris with different concentrations of aqueous shrimp shell extract.

\begin{tabular}{lcccccccc}
\hline \multirow{2}{*}{ X. campestris } & \multirow{2}{*}{ Unit } & \multicolumn{6}{c}{ Concentration of the shrimp shell used in the aqueous extract (\%) } \\
& & $2 \%$ & $5 \%$ & $6 \%$ & $7 \%$ & $8 \%$ & $9 \%$ & $10 \%$ \\
\hline \multirow{2}{*}{1182} & $\mathrm{~g} \cdot \mathrm{L}^{-1}$ & $2.64 \pm 0.1$ & $2.90 \pm 0.3$ & $3.16 \pm 0.4$ & $3.59 \pm 0.3$ & $3.78 \pm 0.1$ & $4.14 \pm 0.2$ & $4.64 \pm 0.4$ \\
& $\mathrm{mPa} \cdot \mathrm{s}^{*}$ & 99.96 & 82.83 & 79.97 & 64.23 & 62.99 & 43.24 \\
\hline \multirow{2}{*}{254} & $\mathrm{~g} \cdot \mathrm{L}^{-1}$ & $2.60 \pm 0.1$ & $2.73 \pm 0.2$ & $2.86 \pm 0.1$ & $3.15 \pm 0.1$ & $3.95 \pm 0.1$ & $4.3 \pm 0.1$ & $4.14 \pm 0.2$ \\
& $\mathrm{mPa} \cdot \mathrm{s}^{*}$ & 85.59 & 85.24 & 74.21 & 51.87 & 51.14 & 37.79 & 37.76 \\
\hline \multirow{2}{*}{629} & $\mathrm{~g} \cdot \mathrm{L}^{-1}$ & $1.95 \pm 0.2$ & $2.01 \pm 0.3$ & $2.14 \pm 0.1$ & $2.38 \pm 0.4$ & $2.49 \pm 0.2$ & $2.56 \pm 0.1$ & $2.65 \pm 0.2$ \\
& $\mathrm{mPa} \cdot \mathrm{s}^{*}$ & 86.90 & 76.54 & 46.86 & 30.98 & 19.88 & 19.54 \\
\hline
\end{tabular}

${ }^{*} 0.5 \%$ aqueous xanthan gum solution, $25 \mathrm{~s}^{-1}$ and $25^{\circ} \mathrm{C}$.

medium composition from different agroindustrial residues, and the fermentation conditions. The conditions used in the present study were similar to those used by Nery et al. [3], except for the strains tested (1866, 2103, and 2149) and the fermentation substrate (whey), the average yield obtained being $12.36 \mathrm{gL}^{-1}$ and viscosity $58 \mathrm{mPa} \cdot \mathrm{s}$. Antunes et al. [10] evaluated the yields of xanthan gums produced by 18 different strains of Xanthomonas campestris pv. pruni, incubated at $28^{\circ} \mathrm{C}$ for 72 hours with agitation at 200 r.p.m in a medium supplemented with $\mathrm{NH}_{4} \mathrm{HPO}_{4}, \mathrm{~K}_{2} \mathrm{HPO}_{4}$ and $\mathrm{MgSO}_{4}$, obtaining yields ranging from $4.1 \mathrm{gL}^{-1}$ to $20.1 \mathrm{gL}^{-1}$. López et al. [22] tested four strains of $X$. campestris to produce xanthan gum using olive mill wastewaters (OMW). The most valuable strain was $X$. campestris NRRL B-1459 S4LII because of its ability to produce xanthan using 7\% of OMW as the nutrient source, producing $7 \mathrm{gL}^{-1}$ of xanthan gum. Kalogiannis et al. [23] studied the xanthan gum production by $X$. campestris ATCC 1395 using pretreated sugar beet molasses as carbon source, supplemented with $\mathrm{K}_{2} \mathrm{HPO}_{4}$, yeast extract, Triton 80 , and tap water. Maximum xanthan gum production was $53 \mathrm{gL}^{-1}$ after $24 \mathrm{~h}$ at $175 \mathrm{gL}^{-1}$ molasses, $4 \mathrm{gL}^{-1} \mathrm{~K}_{2} \mathrm{HPO}_{4}$ and at the initial $\mathrm{pH}=7.0$. Papoutsopoulou et al. [24] used cheese whey as a source of nutrients to produce xanthan gum polymer and the maximum xanthan gum production was $1.2 \mathrm{~g} / 100 \mathrm{~mL}$ of cheese whey by using $X$. campestris XLM 1521 in a medium containing 50\% (m/m) of cheese whey. Cheese whey was also used by Silva et al. [25] as carbon source for xanthan gum production using two strains of Xanthomonas campestris. Maximum xanthan gum productions were observed after $72 \mathrm{~h}$ using cheese whey as sole carbon source, $0.1 \%(\mathrm{~m} / \mathrm{v}) \mathrm{MgSO}_{4}-7 \mathrm{H}_{2} \mathrm{O}$ and $2.0 \%(\mathrm{~m} / \mathrm{v})$ of $\mathrm{K}_{2} \mathrm{HPO}_{4}$, yielding approximately $25 \mathrm{gL}^{-1}$.

In order to determine the best concentration for the alternative medium (SSAE), concentrations from 2 to $10 \%$ $(\mathrm{w} / \mathrm{v})$ were investigated for the three strains (Table 5), and the xanthan gum yields increased with increasing concentration (SSAE). This clearly occurred due to the presence of unconverted substrate, which precipitated with the biopolymer, but on the other hand the viscosity values decreased with increasing concentration (SSAE), suggesting that the bacterial growth could be inhibited by high concentrations of SSAE, which interfered with the biosynthesis of xanthan gum.
Antunes et al. [10] reported that viscosity was the most important property to be considered in the industrial application of xanthan gum.

The viscosity behaviors of the xanthan gums produced by the three strains of $X$. campestris, evaluated in the range from 25 to $85^{\circ} \mathrm{C}$ using a Haake Rheotest viscometer with a concentric cylinder device, were similar, the values decreasing with increasing temperature (Figure 4). This behavior was associated with changes in the conformation of the xanthan molecules as observed by Bradshaw et al. [26]. It was found that in the temperature range from 25 to $85^{\circ} \mathrm{C}$, the viscosity values ranged from 80.74 to $90.36 \mathrm{mPa} \cdot \mathrm{s}$ (gums from sucrose) and from 85.59 to $99.96 \mathrm{mPa} \cdot \mathrm{s}$ (gums from SSAE) (Figure 4).

One important property of xanthan gums is the ability to modify the rheological behavior of solutions. The rheological properties of xanthan gums are mainly related to the chemical composition, arrangement and/or molecular bonding, molar mass, and strain used in the bioconversion [27].

Figure 5 shows the effect of shear rate on the viscosity of the xanthan gums obtained from sucrose and from SSAE, according to the kinetic model $\left(\mu=K(\gamma)^{n-1}\right)$. The highest viscosity value $(99.96 \mathrm{mPa} \cdot \mathrm{s})$ was obtained for the gum from SSAE and strain 1182 at a shear rate of $25 \mathrm{~s}^{-1}$. The viscosity of the gum produced from sucrose under the same conditions was $80.74 \mathrm{mPa}$.s. All the gum solutions showed pseudoplastic fluid behavior, as expected for xanthan gum. The shear rate of chewing varies from $50-200 \mathrm{~s}^{-1}$, and thus from the sensory evaluation standpoint polysaccharides showing pseudoplastic behavior cause less sensation on the buds in the mouth than those with Newtonian behavior [28].

The pseudoplastic behavior of the aqueous xanthan gum solutions was confirmed by fitting the experimental data to the Ostwald-de-Waele model (Table 6).

The consistency $(K)$ and flow $(n)$ indices were obtained by regression analysis, and the values of $n$ for the three strains were very similar. According to Steffe [29], for $K$ values equal to zero and $n$ values between zero and 1 , that is, $0<n<1$, the fluid is considered non-Newtonian and pseudoplastic. The highest value for the flow index $(n)$ and the lowest value for the consistency index $(K)$ were found for the gum produced by strain 254 . Although it was observed that the flow index $(n)$ increased and the consistency index $(K)$ decreased with increasing temperature, this behavior did 


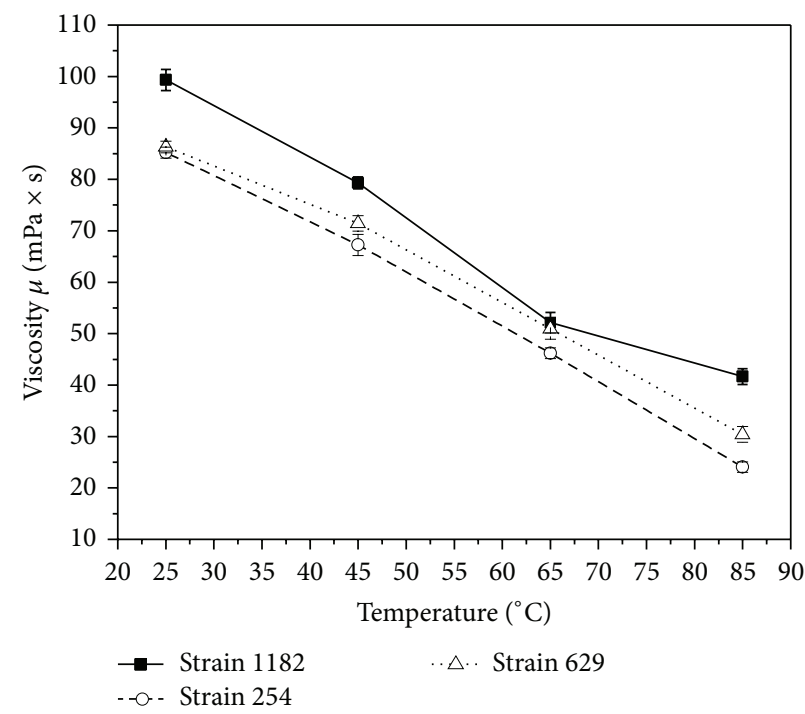

(a)

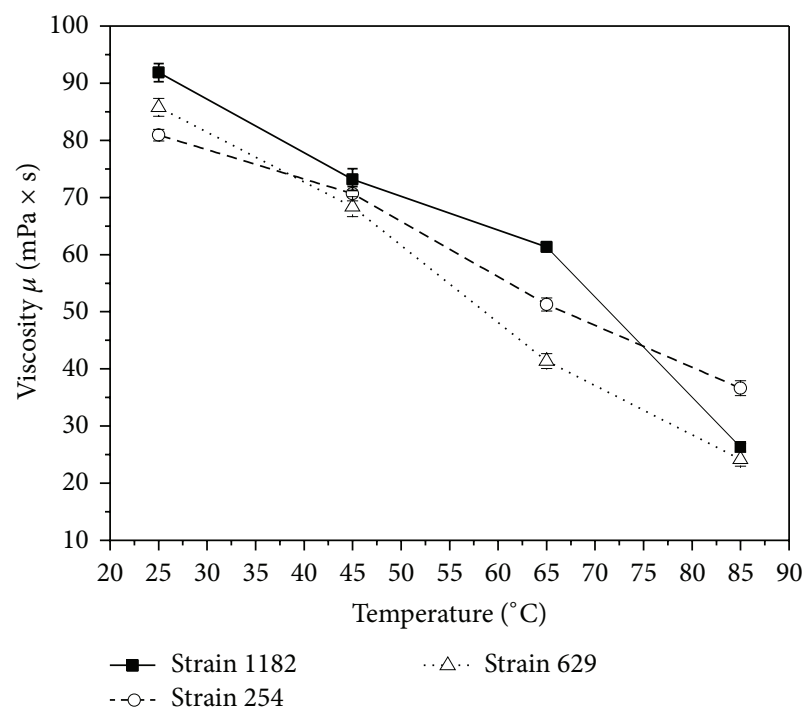

(b)

Figure 4: Apparent viscosities of the xanthan gums ( $0.5 \% \mathrm{w} / \mathrm{v})$ obtained from SSAE (a) and from sucrose (b) at different temperatures (25 to $\left.85^{\circ} \mathrm{C}\right)$. Shear rate is $\gamma 25 \mathrm{~s}^{-1}$.

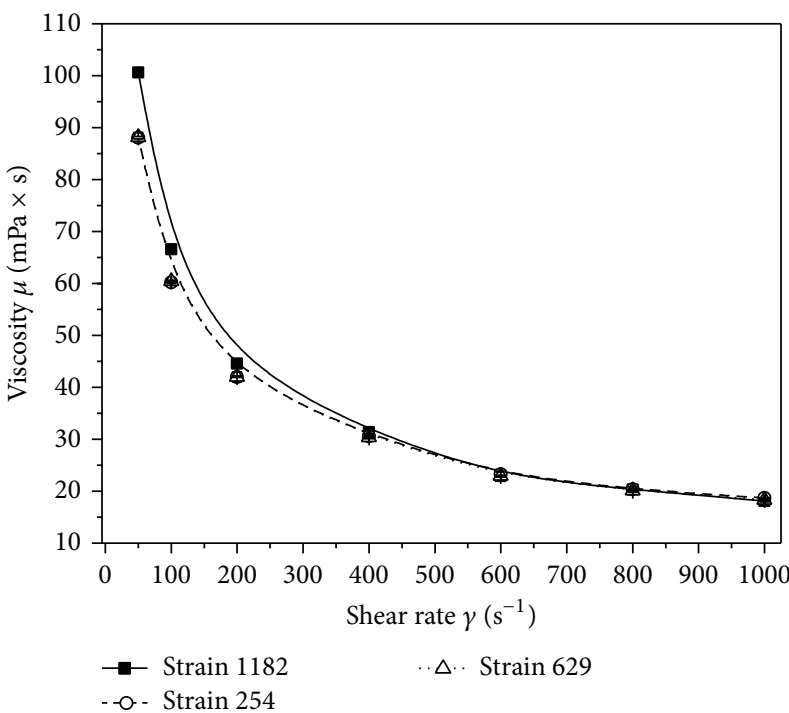

(a)

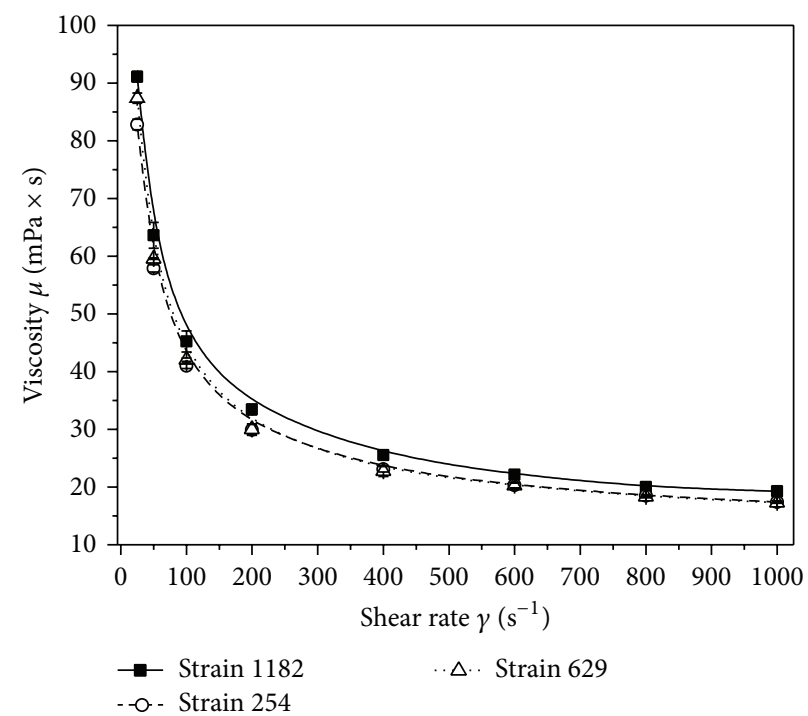

(b)

Figure 5: Apparent viscosities of the xanthan gums ( $0.5 \% \mathrm{w} / \mathrm{v})$ obtained from SSAE (a) and from sucrose (b) at different shear rates $\gamma(25$ to $1000 \mathrm{~s}^{-1}$ ). Temperature is $25^{\circ} \mathrm{C}$.

not affect the apparent viscosity evaluated at shear rates from 25 to $1000 \mathrm{~s}^{-1}$ (Table 6).

When fitted to the Ostwald-de-Waele model, the rheological data obtained for the solutions of xanthan gum obtained from SSAE gave correlation coefficients $\left(R^{2}\right)$ ranging from 0.97 to 0.99 ; that is, the model predicted the behavior of the xanthan gum solutions (Table 6). The Ostwald-de-Waele equation to model the viscosity of xanthan solutions has been employed for several authors. Other authors have used the Casson model for rheological description. Both models show excellent fit to experimental data in the shear rate range of $0.39-79.2 \mathrm{~s}^{-1}[1]$.
Thus, it was shown that the strains tested produced xanthan gum from SSAE and that the strain 1182 produced the highest yield $\left(2.64 \mathrm{gL}^{-1}\right)$ of xanthan gum with the highest viscosity $(99.96 \mathrm{mPa} \cdot \mathrm{s})$ at $2 \% \mathrm{w} / \mathrm{v}$ SSAE.

\section{Conclusions}

In conclusion, the present study showed that the different $X$. campestris strains were able to bioconvert SSAE into xanthan gum, with higher yields and viscosities than those obtained from sucrose. It was observed that the SSAE concentration affected the bioconversion into xanthan gum, the viscosities 
TABLE 6: Values for the flow index $(n)$, consistency index $(K)$, correlation coefficients $\left(R^{2}\right)$, and apparent viscosities of the xanthan gums obtained from the aqueous extract of the shrimp shell by strains of Xanthomonas campestris at different temperatures.

\begin{tabular}{|c|c|c|c|c|c|}
\hline \multirow{3}{*}{$\mathrm{T}\left({ }^{\circ} \mathrm{C}\right)$} & \multicolumn{5}{|c|}{ Rheological parameters* } \\
\hline & \multirow{2}{*}{$n$} & \multirow{2}{*}{$K$} & \multirow{2}{*}{$R^{2}$} & \multicolumn{2}{|c|}{$\mu(\mathrm{mPa} \cdot \mathrm{s})$} \\
\hline & & & & $25 s^{-1}$ & $1000 \mathrm{~s}^{-1}$ \\
\hline & \multicolumn{5}{|c|}{1182} \\
\hline 25 & 0.30 & 936.5 & 0.97 & 99.96 & 7.69 \\
\hline 45 & 0.33 & 792.7 & 0.98 & 99.92 & 7.61 \\
\hline 65 & 0.47 & 287.4 & 0.99 & 52.40 & 7.45 \\
\hline \multirow[t]{2}{*}{85} & 0.48 & 226.0 & 0.99 & 41.93 & 6.08 \\
\hline & \multicolumn{5}{|c|}{254} \\
\hline 25 & 0.37 & 658.9 & 0.99 & 85.59 & 8.25 \\
\hline 45 & 0.40 & 463.3 & 0.99 & 67.78 & 7.49 \\
\hline 65 & 0.46 & 262.1 & 0.99 & 46.50 & 6.41 \\
\hline \multirow[t]{2}{*}{85} & 0.58 & 93.7 & 0.99 & 24.19 & 5.12 \\
\hline & \multicolumn{5}{|c|}{629} \\
\hline 25 & 0.35 & 699.2 & 0.99 & 86.90 & 7.97 \\
\hline 45 & 0.38 & 519.1 & 0.99 & 71.24 & 7.32 \\
\hline 65 & 0.45 & 294.9 & 0.99 & 50.78 & 6.76 \\
\hline 85 & 0.55 & 126.7 & 0.99 & 30.23 & 5.85 \\
\hline
\end{tabular}

decreasing with increasing concentration. The greatest production was achieved after 120 hours of fermentation and subsequently decreased, although it was monitored up to 144 hours. The yields and viscosities values of the xanthan gum produced from SSAE were higher than those produced from sucrose for the three strains studied. The highest viscosities and yields were obtained for Xanthomonas campestris 1182 as compared to strains 254 and 629 , regardless of the substrate used. The xanthan gums, produced from the alternative medium SSAE using three different strains of Xanthomonas campestris, gave $K$ and $n$ values typical of pseudoplastic fluids. The native strain 1182 showed the best performance with respect to the $K$ and $n$ values, the percentage of substrate used, and the viscosity. The use of alternative substrates, such as shrimp shell, can produce xanthan gum with high added value and it eliminates the environmental problems of disposal waste producing a xanthan gum of low cost.

\section{Nomenclature}

\section{Signs}

$K$ : Consistency index $\mathrm{Kg} \cdot \mathrm{m}^{-1} \cdot \mathrm{s}^{n-2}$

$n$ : Flow index

$\mu$ : Behavior index $\mathrm{mPa} \cdot \mathrm{s}$

$R^{2}$ : Correlation coefficient

$\gamma$ : Shear rate $1 /$ second $\left(\mathrm{s}^{-1}\right)$

$\tau$ : Shear stress $\mathrm{mPa}$.

\section{Abbreviations}

SSAE: Shrimp shell aqueous extract.

\section{Conflict of Interests}

The authors declare that there is no conflict of interests regarding the publication of this paper.

\section{Acknowledgments}

Financial support by the Brazilian funding agencies FAPESB, CAPES, CNPq, and Federal University of São João del Rei (UFSJ) is gratefully acknowledged.

\section{References}

[1] F. García-Ochoa, V. E. Santos, J. A. Casas, and E. Gómez, "Xanthan gum: production, recovery, and properties," Biotechnology Advances, vol. 18, no. 7, pp. 549-579, 2000.

[2] J. I. Druzian and A. P. Pagliarini, "Xanthan gum production by fermentation from residue of apple juice," Ciência e Tecnologia de Alimentos, vol. 27, no. 1, pp. 26-31, 2007.

[3] T. B. R. Nery, L. V. Brandão, M. C. A. Esperidião, and J. I. Druzian, "Biosíntese de goma xantana a partir da fermentação de soro de leite: rendimento e viscosidade," Química Nova, vol. 31, no. 8, pp. 1937-1941, 2008.

[4] L. V. Brandão, T. B. R. Nery, M. C. A. Esperidião, and J. I. Druzian, "Produção e viscosidade de goma xantana obtida por fermentação de caldo de cana," Ciênc Tecnol Aliment, vol. 28, pp. 217-222, 2008.

[5] A. Palaniraj and V. Jayaraman, "Production, recovery and applications of xanthan gum by Xanthomonas campestris," Journal of Food Engineering, vol. 106, no. 1, pp. 1-12, 2011.

[6] R. Ben Salah, K. Chaari, S. Besbes et al., "Optimisation of xanthan gum production by palm date (Phoenix dactylifera L.) juice by-products using response surface methodology," Food Chemistry, vol. 121, no. 2, pp. 627-633, 2010.

[7] J. A. Casas, V. E. Santos, and F. García-Ochoa, "Xanthan gum production under several operational conditions: molecular structure and rheological properties," Enzyme and Microbial Technology, vol. 26, no. 2-4, pp. 282-291, 2000.

[8] I. Rottava, G. Batesini, M. F. Silva et al., "Xanthan gum production and rheological behavior using different strains of Xanthomonas sp.," Carbohydrate Polymers, vol. 77, no. 1, pp. 6571, 2009.

[9] A. S. Moreira, J. L. S. Vendruscolo, C. Gil-Turnes, and C. T. Vendruscolo, "Screening among 18 novel strains of Xanthomonas campestris pv pruni," Food Hydrocolloids, vol. 15, no. 4-6, pp. 469-474, 2001.

[10] A. E. C. Antunes, A. S. Moreira, J. L. S. Vendruscolo, and C. T. Vendruscolo, "Screening of Xanthomonas campestris pv pruni strains according to their production of xanthan and its viscosity and chemical composition," Brazilian Journal of Food Technology, vol. 6, no. 2, pp. 317-322, 2003.

[11] M. M. Luvielmo, C. T. Vendruscolo, and A. R. P. Scamparini, "Seleção de linhagens de Xanthomonas campestris para a produção de goma xantana," Semina: Tech Ex, vol. 28, no. 2, pp. 161-172, 2007.

[12] M. E. M. Mabrouk, A. M. D. El-Ahwany, M. M. B. Beliah, and S. A. Sabry, "Xanthan production by a novel mutant strain of Xanthomonas campestris: application of statistical design for optimization of process parameters," Life Science Journal, vol. 10, no. 1, pp. 1660-1667, 2013. 
[13] L. Mayer, C. T. Vendruscolo, W. P. Silva, and A. B. Moura, "Produção, propriedades reológicas e composição química da xantana produzida por Xanthomonas axonopodis pv. Phaseoli," Revista Brasileira de Tecnologia Agroindusstrial, vol. 2, no. 2, pp. 87-95, 2008.

[14] M. Hamcerencu, J. Desbrieres, M. Popa, A. Khoukh, and G. Riess, "New unsaturated derivatives of Xanthan gum: synthesis and characterization," Polymer, vol. 48, no. 7, pp. 1921-1929, 2007.

[15] "Associação Brasileira de Criadores de Camarão-ABCC. Natal: ABCC," 2014, http://abccam.com.br/site.

[16] Association of Official Analytical Chemists (AOAC), Official Methods of Analysis, Rev Arlington, Washington, Wash, USA, 1995.

[17] E. G. BLIGH and W. J. DYER, "A rapid method of total lipid extraction and purification," Canadian Journal of Biochemistry and Physiology, vol. 37, no. 8, pp. 911-917, 1959.

[18] A. S. Souza and C. T. Vendruscolo, "Produção e caracterização dos biopolímeros sintetizados por X. campestris pv pruni c epas 24 e 28," Ciência \& Engenharia, vol. 8, no. 2, pp. 115-123, 1999.

[19] T. B. R. Nery, Estudo da produção e caracterização de goma xantana obtida com novas culturas liofilizadas de Xanthomonas campestris pv [M.S. thesis], Federal University of Bahia, Salvador, Brazil, 2007.

[20] R. P. Chhabra and J. F. Richardson, Non-Newtonian Flow in the Process Industries Fundamentals and Engineering Applications, Butterworth-Heinemann, Oxford, UK, 1999.

[21] A. S. Assis, T. C. M. Stamford, and T. L. M. Stamford, "Bioconversão de resíduos de camarão. Litopenaeus para produção de biofilme de quitosana," Revista Iberoamericana de Polímeros, vol. 9, pp. 480-499, 2008.

[22] M. J. López, J. Moreno, and A. Ramos-Cormenzana, “Xanthomonas campestris strain selection for xanthan production from olive mill wastewaters," Water Research, vol. 35, no. 7, pp. 1828-1830, 2001.

[23] S. Kalogiannis, G. Iakovidou, M. Liakopoulou-Kyriakides, D. A. Kyriakidis, and G. N. Skaracis, "Optimization of xanthan gum production by Xanthomonas campestris grown in molasses," Process Biochemistry, vol. 39, no. 2, pp. 249-256, 2003.

[24] S. V. Papoutsopoulou, L. V. Ekateriniadou, and D. A. Kyriakidis, "Genetic construction of Xanthomonas campestris and xanthan gum production from whey," Biotechnology Letters, vol. 16, no. 12, pp. 1235-1240, 1994.

[25] M. F. Silva, R. C. G. Fornari, M. A. Mazutti et al., "Production and characterization of xantham gum by Xanthomonas campestris using cheese whey as sole carbon source," Journal of Food Engineering, vol. 90, no. 1, pp. 119-123, 2009.

[26] I. J. Bradshaw, B. A. Nisbet, M. H. Kerr, and I. W. Sutherland, "Modified xanthan-its preparation and viscosity," Carbohydrate Polymers, vol. 3, no. 1, pp. 23-38, 1983.

[27] AS. Moreira, Produção, caracterização e aplicação de biopolímero sintetizado por cepas de Xanthomonas campestris pv pruni [Ph.D. thesis], Federal Univeristy of Pelotas, Pelotas, Brazil, 2002.

[28] E. R. Morris, "Rheology of hydrocolloids," in Gums and Stabilisers for the Food Industry, G. O. Philips, D. J. Wedlock, and P. A. Williams, Eds., vol. 2, pp. 57-78, Pergamon Press, Oxford, UK, 1984.

[29] J. F. Steffe, Rheological Methods in Food Process Engineering, Freeman Press, Michigan, Mich, USA, 1996. 

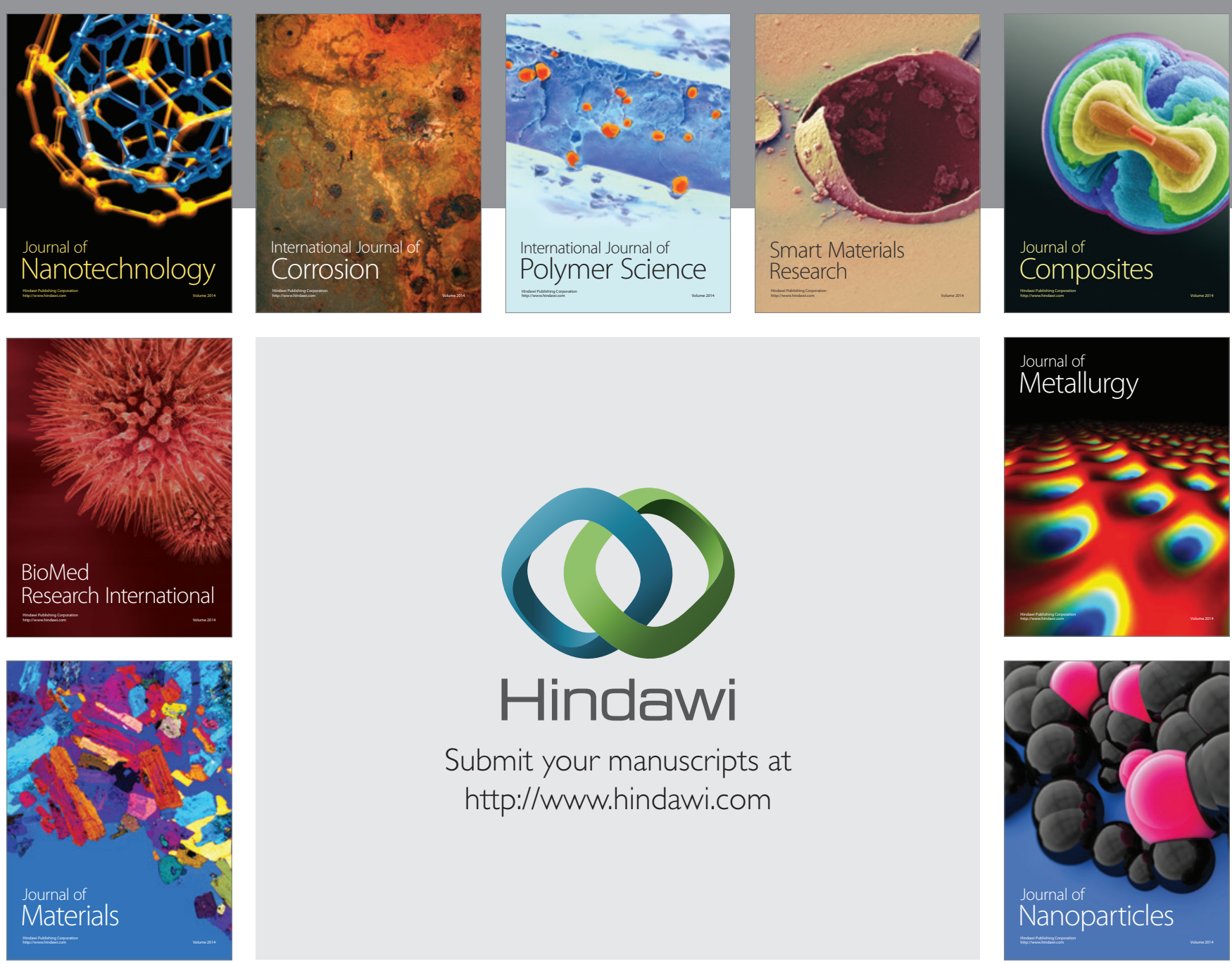

Submit your manuscripts at http://www.hindawi.com
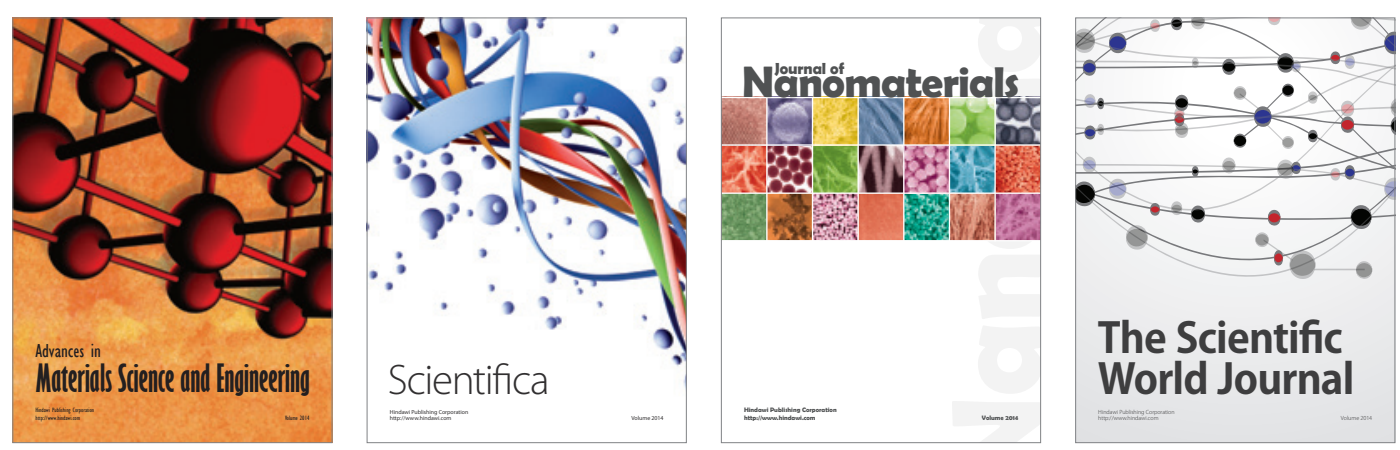

\section{The Scientific World Journal}
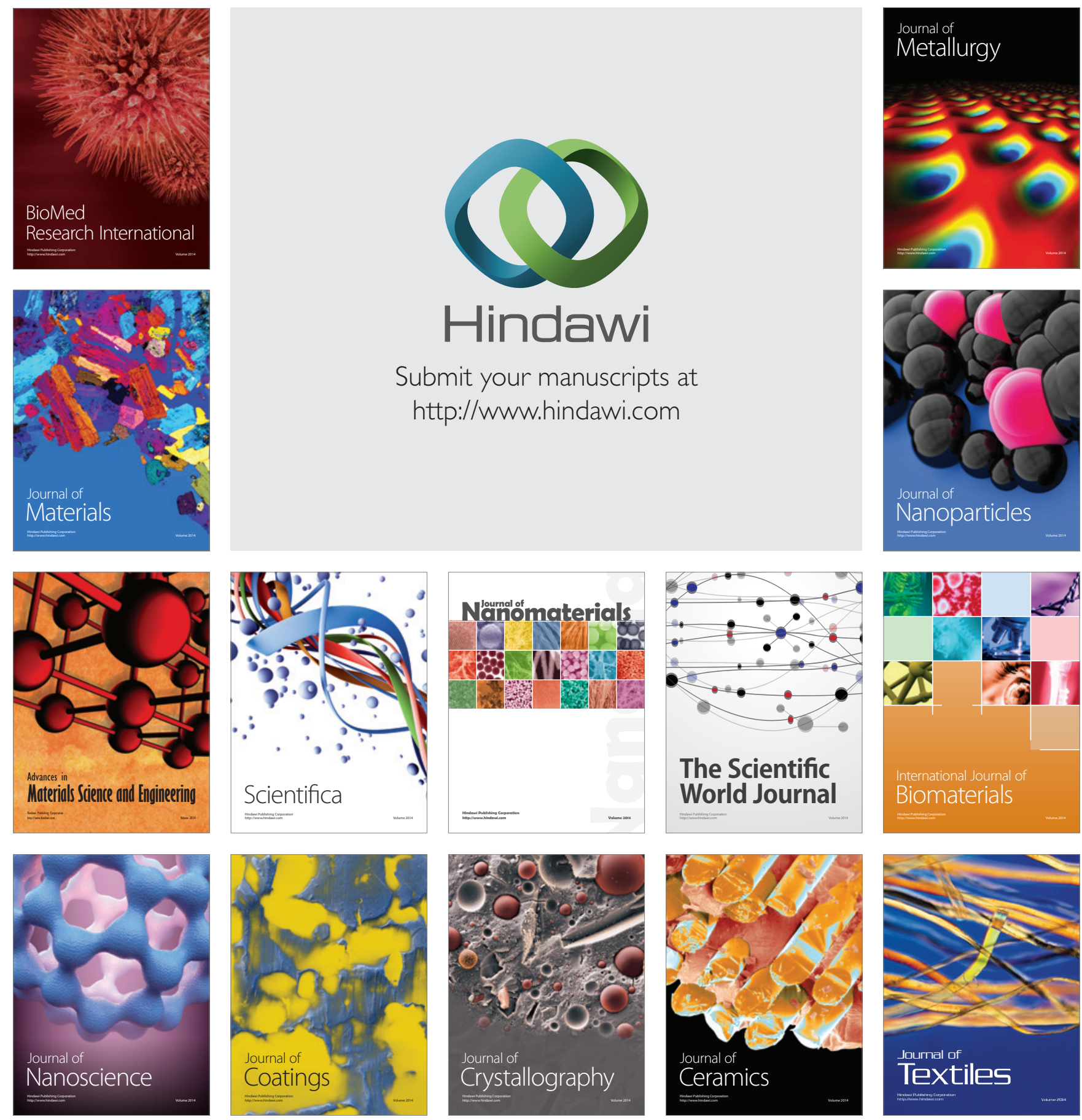